KATARZYNA JĘDRASZCZYK

Uniwersytet im. Adama Mickiewicza

WŁADIMIR RABINOWICZ

Irkucki Uniwersytet Państwowy
Images

vol. XVII/no. 26

Poznań 2015

ISSN 1731-450x

\title{
Obraz Aleksandra Kołczaka $i$ wojny domowej $w$ Rosji, przedstawiony w filmie Admirał, a współczesna rosyjska świadomość historyczna
}

Transmisja obrazów zbiorowej pamięci w społeczeństwie odbywa się za pośrednictwem rozmaitych kanałów, w tym także związanych z szeroko pojętą sztuką. Obrazy przeszłości tworzone przez artystów i literatów wywierają silniejszy wpływ na widza niż wielotomowe prace naukowe historyków. Zjawisko to wynika przede wszystkim z faktu, iż tego rodzaju przekaz jest bardziej zrozumiały, wyrazisty, dostępny, lepiej zapamiętywany, a ponadto sprawniej upowszechniany i „dystrybuowany" niż wielotomowe prace akademickie.

Pamięć o wojnie domowej w Rosji i związanych z nią bohaterach i antybohaterach jest wciąż aktualnym tematem dla współczesnych obywateli kraju. Przez cały okres władzy radzieckiej treści związane z wojną domową po rewolucji 1917 roku przedstawiane były w sztuce i w historiografii bardzo jednostronnie. Uczestników walk dzielono na „naszych” i „nie naszych”: na bolszewików i ich przeciwników, czyli „wrogów narodu”. Przedstawiciele „białych”, a szczególnie ich przywódcy i zwierzchnicy wojskowi, charakteryzowali się odrażającymi cechami charakteru i brakiem patriotyzmu. Dezawuowano lub w ogóle nie wspominano o ich zasługach i karierach z okresu przedrewolucyjnego. Jednym $z$ najlepszych przykładów takiego sposobu kreowania wizerunku „wroga narodu” była postać Aleksandra Kołczaka, który zyskał w Związku Radzieckim przydomek „krwawy” i „sprzedawczyk”.

W listopadzie 2014 roku minęło 140 lat od dnia urodzin Aleksandra Wasiliewicza Kołczaka - jednej z najważniejszych i jednocześnie najbardziej kontrowersyjnych postaci rosyjskiej historii XX wieku. Powszechne zainteresowanie jego dziejami nastąpiło wkrótce po premierze kinowej historyczno-wojennego filmu fabularnego pt. Admirat. Po roku zainteresowanie postacią podtrzymał dziesięcioodcinkowy serial pod tym samym tytułem, będący rozwiniętą wersją produkcji kinowej. Należy podkreślić, iż w Rosji wiele filmów o tematyce historycznej zorientowanych jest na szerokie audytorium i odpowiada na określone potrzeby społeczne, a czasem także polityczne. Pojawienie się na ekranach kin 
i telewizorów filmu, którego bohaterem był jeden z najważniejszych przywódców „białych”, niewątpliwie świadczy o próbie przedstawienia widzom w Rosji nowej interpretacji wydarzeń z okresu wojny domowej.

Film Admirał w reżyserii Andrieja Krawczuka zyskał w Rosji miano „produkcji narodowej”[1]. Był jednym z najdroższych filmów $\mathrm{w}$ historii kina rosyjskiego, kosztował $20 \mathrm{mln}$ USD (razem z wersją serialową)[2]. Obejrzało go w rosyjskich kinach 5,4 mln widzów i ok. 6,2 mln na świecie[3]; przyniósł dochód 38135878 USD na świecie i 34518207 w Rosji[4]. Film został udostępniony w liczbie 1250 kopii, co w praktyce oznaczało możliwość pokazania go we wszystkich z ponad siedmiuset kinoteatrów Rosji. Z czasem w sprzedaży pojawiły się $2 \mathrm{mln}$ płyt DVD[5]. Miarą sukcesu filmu były badania przeprowadzone przez Wszechrosyjskie Centrum Badań Opinii Publicznej (ВЦИОМ) 13-14 grudnia 2008 roku. Film był, zdaniem 15 proc. respondentów, najpopularniejszą produkcją roku, na drugim miejscu znalazł się film Nikity Michałkowa pt. Dwunastu (z wynikiem 7 proc.). W rankingu najlepszych aktorów zwyciężył odtwórca roli Aleksandra Kołczaka Konstantin Chabienski (14 proc.), podczas gdy rok wcześniej to samo miano przyznawało mu tylko 3 proc. badanych. Najbardziej zaskakujący był fakt, że Konstantin Chabienski zajął trzecie miejsce w rankingu „ulubionych Rosjan”, ustępując tylko Władimirowi Putinowi i Alle Pugaczowej, a rok wcześniej aktora w ogóle nie było w pierwszej dziesiątce[6].

Postać Kołczaka i tematyka wojny domowej nie była silnie eksploatowanym motywem w radzieckiej i rosyjskiej sztuce kinowej. Najstarszym obrazem kinowym o tej tematyce był Krasnyj gaz (1924) w reżyserii Iwana Kałabuchowa. Idea filmu zrodziła się w piątą rocznicę „wyzwolenia” Syberii od Kołczaka. Jednym z inicjatorów jego powstania był członek Syberyjskiego Biura Wszechzwiązkowej Komunistycznej Partii (bolszewików) Weniamin Wegman[7]. Akcja filmu rozgrywa się w guberni syberyjskiej. Bohaterka Barbara Cziepałowa, dowiadując się o śmierci brata, zaciąga się do oddziału partyzantów i rozpowszechnia wśród kołczakowskich żołnierzy bolszewickie proklamacje (tytułowy „czerwony gaz”, czyli bolszewicką propagandę, która jak gaz ma zdolność przenikania wszędzie). W ekipie zdjęciowej znalazł się m.in.

[1] Sud'ba admirała. Interwju z Andriejem Krawczukom, „Wokrug swieta” 2008, nr 10 (2817).

[2] L. Jusipowa, Bjudżet Admirała - 20 milionow dollarow. Interwju $z$ A. Maksymowym i D. Fajzijewym, „Izwiestia” [online], 9 listopada 2008 [dostęp: 25 stycznia 2015], <http://izvestia.ru/news/341591>.

[3] Bardziej popularny był tylko film Ironia sud'by (2007), który obejrzało prawie 8800 ooo widzów, oraz Stalingrad (2013), który obejrzało ok. 6200000 widzów. Patrz: <http://www.kinopoisk.ru/box/ best_people_rus/>. W Polsce premiera odbyła się 9 listopada 2009 roku (3360 widzów, dystrybucja Kino Świat - bez dystrybucji kinowej, sprzedaż DVD z polskim lektorem).
[4] Samyje kassowyje filmy [online, b.d.], [dostęp: 25 stycznia 2015], <http://www.kinopoisk.ru/box/ best_rus/>.

[5] Tiraż 125 raboczich kopij [online, b.d.], [dostęp: 25 stycznia 2015], <http://admiralfilm.ru/peace/news/ document343.phtml>.

[6] Euczszij film 2008 goda: somnitielnaja pobieda Admirała [online, b.d.], [dostęp: 25 stycznia 2015], $<$ http://wciom.ru/index.php?id=269\&uid=11170, Film>.

[7] W. Watolin, Golliwud za Kamienkoj. Oczierki zarożdienija $i$ stnowlienija proizwodstwa filmow $w$ Sibiri, „Kinowiedczieskije zapiski” nr 70, 2004, s. 220-230. 
były kołczakowski oficer Gieorgij Pożarickij, który później podczas masowych represji został aresztowany. Krasnyj gaz był pierwszym filmem zrealizowanym na Syberii w Nowonikołajewce (Nowosybirsku). Nie zachowała się do naszych czasów żadna kopia, pozostały jedynie fragmenty taśmy filmowej, które załączono do akt sprawy sądowej represjonowanego Gieorgija Pożarickiego. Rolę Kołczaka zagrał Michaił Lenin[8].

Temat wojny domowej w Rosji zniknął ze scenariuszy filmowych aż do czasu chruszczowowskiej „odwilży”. W roku 1956 na ekrany kin wszedł Sorok pierwej na motywach powieści pod tym samym tytułem, w reżyserii Grigorija Czuchraja. Główny bohater filmu, porucznik Wadim Nikołajewicz Goworucha-Otrok, jest pełnomocnikiem rządu Kołczaka w obwodzie zakaspijskim. Czuchraj jako jeden z pierwszych pokazał ogólnonarodową tragedię konfliktu „białych” i „czerwonych”.

Pierwszą spójną próbą ukazania życia Kołczaka był film z roku 1959 pt. Zołotoj eszelon. Ten dramat wojenny w reżyserii Ilii Gurina rozgrywa się w roku 1919 na Syberii. Admirał Kołczak próbuje wywieźć za granicę część skarbca carskiej Rosji. W ostatnim momencie dowiadują się o tym bolszewicy i decydują się na przechwycenie pociągu. Ostatnie kilka kilometrów do granicy staje się polem bitwy pomiędzy „białymi” i „czerwonymi”. W filmie wystąpił m.in. Wasilij Szukszyn, Michaił Kazakow. Kołczaka grał Aleksander Szatow. W fikcyjnej fabule pojawiają się prawdziwe postaci historyczne.

Kolejnym filmem, gdzie pojawia się temat wojny domowej, był nakręcony w roku 1968 dramat wojenny pt. Groza nad Biełoj w reżyserii Jewgienija Nemczenki i Stanisława Czaplina, opowiadający o epizodzie związanym w walkami armii Kołczaka i armii Frunzego o zdobycie Ufy. W roku $1971 \mathrm{w}$ Swierdłowskim studiu filmowym powstał film Koczujuszczij front w reżyserii Barasa Chałzanowa, opowiadający o mało znanym epizodzie wojny domowej - powstaniu w 32 syberyjskich wsiach, które zjednoczyły się jako Badżejska Republika. Kołczak rzucił przeciwko republice dwunastotysięczną armię [9].

O ważnym epizodzie w życiorysie Kołczaka związanym z ekspedycjami polarnymi opowiada film Ziemlja Sannikowa (1973) w reżyserii Alberta Mkrtczana. Pierwotnie fabuła filmu miała się opierać na motywie ekspedycji, w której uczestniczył Kołczak, ale z przyczyn politycznych scenariusz zmodyfikowano, zmieniając opowieść w baśń przygodową, której bohater ma jedynie pewne rysy swojego pierwowzoru. W okresie pierestrojki w roku 1987 na ekrany wszedł dwuodcinkowy wojenno-historyczny film Moonzund na motywach powieści Walentyna Pikulia. Akcja filmu rozgrywa się w latach 1915-1917 i opowiada o walkach floty rosyjskiej na Bałtyku podczas pierwszej wojny światowej. Pokazano tu rozgromienie floty i warunki, w jakich rodziła się rewolucja. Rolę Kołczaka zagrał Jurij Bieliajew. Był bodaj pierw-

[8] Prawdziwe nazwisko Ignatiuk - pseudonim nie miał związku $\mathrm{z}$ wodzem proletariatu i wybrany był jeszcze przed rewolucją.
[9] Film można obejrzeć na stronie: <https://www. youtube.com/watch?v=mJAiIHJufXk $>$ [dostęp: 19 stycznia 2015]. 
szym aktorem, który pokazał tę postać w sposób wielowymiarowy, jako człowieka, którego trudno jednoznacznie ocenić, w odróżnieniu od karykaturalnie nakreślonych figur Kołczaka w filmach wcześniejszych. W roku 1988 kilku aktorów za role w tym filmie otrzymało srebrne medale im. Aleksandra P. Dowżenki.

W okresie poradzieckim postać Kołczaka szerzej zaprezentowano w ósmej części dziesięcioodcinkowego dramatu historycznego Koń biełyj[10] (1993, reż. Gelij Riabow). Film opowiada o Rosji w przeddzień rewolucji. Po raz pierwszy wnikliwie pokazano tragiczny los Kołczaka, losy carskiej rodziny oraz okoliczności śledztwa, zleconego przez admirała w sprawie śmierci cara. Film pokazuje bezwzględność władzy i bezmyślność, która prowadzi do upadku kraju.

Postać Kołczaka przybliżyły też filmy dokumentalne: Dorogoj moj, Wierchownyj prawitiel w reżyserii Walerji Łowkowej (1990), Bolszje cziem ljubow Sergieja Jurżenki (1997), a szczególnie Nikity Michałkowa Diałogi z Kołczakom (2003)[11], który w wyraźny sposób uzupełnił wiedzę na temat „białych” i Kołczaka.

W roku 1998 odważnej próby przedstawienia życia Kołczaka w formie sztuki teatralnej podjął się reżyser Wiaczesław Kokorin. Na deskach Teatru Dramatycznego w Irkucku wystawiono sztukę Siergieja Ostroumowa pt. Zwiezda generała. Irkucki Akademicki Teatr Dramatyczny im. N.P. Ochłopkowa w listopadzie 2005 roku zaprezentował przedstawienie pt. Wstrieczi $z$ admirałom Kołczakom na podstawie dramatu Siergieja Ostroumowa[12].

Najważniejszym jednak filmem pozostaje superprodukcja pt. Admirat. Pierwotny tytuł $D a$, ja admirał Kołczak (Tak, ja jestem admirał Kołczak) zamieniono na Admirat, używając archaicznego zapisu słowa „admirał” z twardym znakiem na końcu. Nie było to zresztą przypadkowe. W warstwie skojarzeniowej nawiązywać miało do przedrewolucyjnego porządku, którego obrońcą jest w filmie Kołczak.

Fabuła filmu nie jest szczególnie skomplikowana $\mathrm{z}$ powodu podporządkowania jej jednej tezie - ukazaniu admirała Kołczaka jako bohatera odchodzących czasów, oddanego ojczyźnie i idei. Niektóre obrazy wymagały jednak retuszu, inne - podkreślenia.

W filmie uwypuklono motyw religijny - kilkakrotnie pojawia się święta ikona jako symbol wartości, które uosabia admirał, odchodzących wraz z nadejściem bolszewickiej nawały. Kołczak udaje się do kwatery cara Mikołaja II (car jest tu postacią wręcz mistyczną). Wręczając ikonę i błogosławiąc Kołczaka, monarcha niejako powierza mu los Rosji. Symboliczny jest też obraz heroicznej walki na morzu z wrogim okrętem niemieckim, którego załoga, pomimo znaczącej przewagi militarnej, przegrywa $\mathrm{z}$ hartem ducha i żarliwą modlitwą za-

[10] Odcinek ósmy serialu: <https://www.youtube. com/watch?v=qjO-7zz7Ays> [dostęp: 20 stycznia 2015].

[11] Film dostępny: <https://www.youtube.com/
watch?v=7t938di-Byg $>$ [dostęp: 20 stycznia 2015]. [12] Spektakl patrz: <https://www.youtube.com/ view_play_list?p=73A9B68CBB77464C > [dostęp: 20 stycznia 2015]. 
łogi okrętu rosyjskiego. Powodzenie misji okazuje się zależeć nie tylko od odważnej decyzji Kołczaka o odwrocie przez zaminowany obszar morza, ale przede wszystkim - od kolektywnej modlitwy prostych marynarzy i wspólnego przeświadczenia, że dla Boga i cara warto ginąć.

Najważniejszym motywem filmu jest jednak temat miłości admirała Aleksandra Kołczaka i Anny Timiriowej, rozgrywającej się na uboczu rewolucji i wojny domowej. Dość karkołomnym zadaniem dla reżysera było pokazanie wątpliwego moralnie związku (zarówno Anna, jak i Aleksander w momencie nawiązania romansu mają swoich prawowitych małżonków) jako uczucia pięknego, nieuchronnego i pełnego poświęcenia. Kołczak wprawdzie próbuje opierać się miłości, ale przegrywa, porwany oddaniem Anny. Zdradę Anny widz znosi łatwo, bo mąż kobiety, do niedawna towarzysz admirała w bitwach morskich, przechodzi na stronę „czerwonych”. W powszechnym odbiorze jako człowiek, który porzuca ideały, nawet jako kochający mąż Anny, zasługuje na porzucenie[13]. Anna towarzyszy Kołczakowi w ostatnich miesiącach jego życia.

Obraz ten jest ważny także ze względu na ogólny przekaz dotyczący kina rosyjskiego, dotychczas kojarzonego na Zachodzie ze słabym jakościowo filmem sensacyjnym lub gloryfikacją czasów komunizmu. Ta produkcja miała być wyraźnie antysowiecka. Jednocześnie pokazywała, że chaos, który niosą zmiany polityczne, zawsze jest dla państwa niebezpieczny. Wojna wewnętrzna ukazana w filmie prowadzi widza ku refleksji, że „nowe” niesie destrukcję, a każda stabilność, nawet nie do końca zadowalająca, jest najważniejszą wartością. Bolszewicy to „biomasa”, bezimienne zło, które burzy stary świat, nie mając wizji nowego[14]. Destrukcja wchodzi w życiorysy ludzi, łamie ich życie, plącze losy, rozbija rodziny. Bezsensowność wojny domowej pokazuje scena walki kappelowców[15] z „czerwonymi”. „Biali” umierają jeden po drugim, heroicznie, ale i daremnie. Uporządkowany świat Kołczaka i jemu podobnych odchodzi bezpowrotnie, pozostaje tylko sentyment (scena pod koniec filmu, kiedy Anna Timiriowa wspomina dawne życie na salonach). Jeden ze sloganów zwiastujących premierę filmu brzmiał „pozostał wierny odchodzącej starej Rosji”. Bolszewików motywuje ideologia, Kołczaka i jemu podobnych - wiara w powrót dawnych wartości i dawnego porządku. Uosobieniem tego świata jest uroda i dworski styl Anny.

Film ma pewne przesłanie ideologiczne. Doskonale pokazuje to komentarz do filmu pisarza i publicysty Lwa Anninskiego, przedstawiony w Rossijskoj gazietie: „Państwo nie może osiedlić człowieka w raju,

[13] I. Smirnow, Prostranstwo Kołczaka na ekranie [online], 23 października 2008 [dostęp: 12 stycznia 2015] , <http://www.svoboda.org/content/transcript/470328.html\#top>; I. Smirnow, „Admirat”. Kriestnyj chod ot muża k lubowniku, „Skepsis” [online], 23 października 2008 [dostęp: 12 stycznia 2015], $<$ http://scepsis.net/library/id_2218.html>.

[14] A. Archangielskij, Był pariadok, „Ogoniok” [on- line], 13-19 października 2008, $\mathrm{nr} 43$ [dostęp: 13 stycznia 2015], <http://www.ogoniok.com/5068/11/>. [15] Władimir Kappel - dowódca tzw. wielkiego syberyjskiego lodowego marszu „białych”, dowodził wojskami osłaniającymi pochód Kołczaka na wschód wzdłuż kolei transsyberyjskiej. Po jego śmierci w styczniu 1920 roku zastąpiony przez Siergieja Wojciechowskiego. 
ale może ocalić go od piekła. Ale do tego potrzebna jest praca w pocie czoła i znoszenie smutków. I dzięki temu można być szczęśliwym”[16]. Andriej Sacharow, dyrektor Instytutu Historii Rosji, stwierdził, komentując film, że Rosjanie powinni

[...] przywrócić historię wraz z jej wszystkimi znaczeniami i personaliami, które wcześniej były zakazane i przemilczane. Niewłaściwe jest mówienie, że trzeba rehabilitować białych czy czerwonych. Co tu rehabilitować, jeśli ludzie walczą o swoje przekonania i wartości przeciw tym, którzy próbują nimi wstrząsnąćc [17].

W podobny sposób ideę filmu oddał filozof rosyjski Grigorij Pomieranc:

Zwycięstwo najczęściej zależy od umiejętności dochodzenia do kompromisu. W klęsce Kołczaka, według mnie, decydującą rolę odegrała nieszczęsna rosyjska niemożność zawierania kompromisów [...]. Wojna domowa to straszna rzecz. Ludzie na niej stają się szatanami [...][18].

Zaangażowanie emocjonalne widzów przejawia się zwłaszcza w recenzjach i wrażeniach widzów. Film był szczególnie ważny dla mieszkańców Irkucka, w którym główny bohater spędził ostatnie dni swojego życia. W roku 1902 jako hydrograf polarnik przy pełnej sali w Irkuckim Oddziale Rosyjskiego Towarzystwa Geograficznego (obecnie jest to budynek Muzeum Etnograficznego w Irkucku) prezentował naukowe wyniki ekspedycji poszukującej mitycznej wyspy-widma na Oceanie Arktycznym - Ziemi Sannikowa[19]. Szczęśliwym zbiegiem okoliczności w audytorium przebywał także Władimir Obruczew - znany geolog i geograf, który spisał historię wyprawy, a motyw ten posłużył za kanwę powieści fantastycznonaukowej Ziemlja Sannikowa (a potem także wspomnianego wyżej filmu). Podczas wyprawy prowadzono wartościowe badania dotyczące Arktyki. Imieniem Kołczaka nazwano także wyspę w pobliżu Tajmyru, a Kołczak został nagrodzony przez Rosyjskie Towarzystwo Geograficzne Wielkim Medalem Konstantinowskim. W Irkucku w cerkwi Charłampijewskiej (obecnie Michajło-Archangielskiej) w roku 1904 odbył się ślub Kołczaka z Zofią Omirową, która przybyła tu za narzeczonym z Petersburga[20]. W roku 1919 w Irkucku mieściła się też siedziba rządu Kołczaka, a potem bolszewicy rozstrzelali admirała nad rzeczką Uszakowką (dopływ Angary). Mieszkańcy Irkucka w roku 2004 postawili Kołczakowi pomnik - jedyny taki w całej Rosji[21]. Miejscowe muzeum etnograficzne posiada w swych zbiorach kolekcję fotografii i dokumentów związanych z pobytem Kołczaka w Irkucku.

[16] N. Lebiediewa, E. Jakowlewa, Admirał Kołczak snowa roskołał Rossiju, „Rossijskaja Gazieta” [online] N4779 от 23.10.2008 [dostęp: 20 stycznia 2015], $<$ http://www.rg.ru/2008/10/23/kolchak.html>.

[17] Ibidem.

[18] Ibidem.

[19] Wyprawa, w której uczestniczył Kołczak, potwierdziła, że wyspa nie istnieje. Podstawą wcześniejszych wątpliwości była ekspedycja Sannikowa z początku XIX wieku. Być może lądolód istniał, ale uległ roztopieniu wraz z ociepleniem klimatu.

[20] Ze związku z Zofią urodziło się troje dzieci. Dwie córki, które umarły w dzieciństwie, i syn Rościsław. [21] Upamiętnienia w Moskwie i Petersburgu podkreślają zasługi Kołczaka jako polarnika i dowódcy floty i nie są pomnikami, a raczej płytami pamiątkowymi. Tylko pomnik w Irkucku ma charakter polityczny. Upamiętnienie Kołczaka jako polarnika 
Po ślubie Kołczak udał się do Port Artur, w samo centrum wojny rosyjsko-japońskiej. Doznał tam poważnych ran. Wojskowa komisja orzekła niezdolność Kołczaka do służby wojskowej, ale jego talenty analityczne i temperament ambitnego oficera dostrzegł komendant Floty Pacyfiku admirał Makarow. Nie pozwolił mu odejść z marynarki. Po porażce w wojnie $\mathrm{z}$ Japonią zaistniała konieczność reform w marynarce. Kołczak z sukcesem zajął się reorganizacją rosyjskiej marynarki wojennej i przekształceniem jej w Generalny Sztab Morski. Jego prace naukowe dotyczące rozwoju rosyjskiej floty wykorzystały później władze Związku Radzieckiego, nie ujawniając nazwiska autora. W czasie pierwszej wojny światowej Kołczak trafił w miejsca trudnych walk na Morzu Bałtyckim, a potem na Morzu Czarnym i w rezultacie dosłużył się stopnia kontradmirała. Jesienią 1918 roku przybył do Omska, gdzie został wyznaczony na ministra wojny i marynarki w antybolszewickim rządzie koalicyjnym (zwanym też Rządem Syberyjskim lub Dyrektoriatem) z siedzibą w Omsku. Wkrótce z grupą kadetów i oficerów niezadowolonych z rządów Dyrektoriatu Kołczak dokonał przewrotu. Ustanowiwszy dyktaturę, ogłosił się „Wielkorządcą Państwa Rosyjskiego" (Wierchownyj Prawitiel Rossijskowo Gosudarstwa). Podporządkowana mu Rada Ministrów nadała mu stopień admirała. Po prawie roku walk w listopadzie 1919 roku padł Omsk, a Kołczak przeniósł rząd do Irkucka. Wkrótce jego armię rozgromili „czerwoni”. Na początku stycznia 1920 roku Kołczak zrezygnował z funkcji, przekazując swe pełnomocnictwa gen. Antonowi Denikinowi. W Irkucku admirał został rozstrzelany. Do końca towarzyszyła mu Anna Timiriowa. Pamięć o Kołczaku przetrwała wśród wielu jego byłych żołnierzy, oficerów i kozaków.

Znaczenie Irkucka dla Kołczaka podkreślili także dystrybutorzy filmu Admirał, organizując pokaz przedpremierowy w irkuckim kinoteatrze „Barguzin” 8 października 2008 roku - dzień przed oficjalną premierą. Nadano temu wydarzeniu nadzwyczajną oprawę, która budziła skojarzenia z czasami przedrewolucyjnej carskiej Rosji. Zaproszonych na pokaz widzów witała orkiestra ubrana w mundury $\mathrm{z}$ akselbantami, w foyer w blasku świec stały stoły nakryte obrusami, gości częstowano szampanem. Prasa zwracała uwagę także na niecodzienne gadżety reklamowe, jakie wręczano widzom - stylizowane na stare fotografie pocztówki z wizerunkami bohaterów filmu (Konstantina Chabienskiego i Jelizawiety Bojarskiej) i zapałki w okolicznościowych pudełkach[22].

w Moskwie (2008) patrz: <http://vk.com/photo328467_118429231> i dewastacja płyty w roku 2008 patrz: <http://vk.com/photo-328467_118736075>. W Omsku, podobnie jak w Irkucku, była to prywatna inicjatywa, zrealizowana na prywatnym gruncie w roku 2012. Właściciel restauracji „Kołczak”, upamiętniając admirała, wywołał gorące dyskusje o roli Kołczaka w historii Omska. Były gubernator obwodu omskiego Leonid Polieżajew bezskutecznie lobbuje na rzecz „prawdziwego” pomnika. Komentarze: <http:// smartnews.ru/regions/omsk/1599.html>, w roku 2012: $<$ http://vk.com/photo-328467_304314315>. Co znamienne - płyta i pomnik w Omsku odsłonięte zostały w dniu Jedności Narodowej w Rosji (4 listopada). [22] A. Bogatych-Kork, W Irkutskie Admirała uwidieli rańsze, „SM Nomier odin” [online], 9 października 2008, nr 40 [dostęp: 10 stycznia 2015], <http://baikalpress.ru/sm/2008/40/oo9oo1.html>. 
Rehabilitacja Kołczaka miała wymiar codzienny, ale i kulturalny. Najpierw pojawiała się marka piwa „Kołczak”, a w roku 1998 wspomniany już spektakl Zwiezda admirała. Autor sztuki dopełnił projekt także albumem romansów o miłości i wojnie.

Po rozpadzie Związku Radzieckiego w Irkucku powstało wiele pomników, ale tylko jeden pretendował do miana „twarzy” miasta. Był to pomnik nie Kołczaka-dowódcy marynarki czy Kołczaka-naukowca, lecz postaci wojny domowej, dowódcy „białych”. Postawienie pomnika zwykle wymaga przejścia przez pierwszy etap - racjonalizację, czyli rozważanie argumentów „za” i „przeciw”, refleksję nad „rolą” i „miejscem”, „koniecznymi działaniami”, dyskusję wokół historii i jej roli w życiu potomnych. Nierzadko w krajach o trudnej historii wywołuje to raczej polemikę niż konstruktywną ocenę argumentów. Polemika zwykle ogranicza się do przestrzeni internetowej, przypomina wyrzut emocji, które interesują tylko uczestników i nie prowadzą do konsensusu. Dyskusja poza forami aktywistów, bez zbędnych emocji, zdarza się rzadko, potrzeba na nią bowiem więcej czasu. Prawdopodobnie spodziewając się takiego scenariusza wydarzeń, inicjatorzy zbudowania pomnika Kołczakowi - stowarzyszenie „Patriot” - postanowili działać, stawiając społeczność Irkucka przed faktem dokonanym. Dla obserwatora zewnętrznego budowa monumentu była szybka i nieoczekiwana, a komentarze wybrzmiewały jakby z opóźnieniem, po faktach. Pomnik postawiono (czy raczej zmuszono miasto do zaakceptowania jego obecności) w roku 2004 - w 130. rocznicę urodzin Kołczaka. Inicjatorzy budowy oświadczyli, że pomnik został wykonany przez rzeźbiarza, który postanowił podarować go mieszkańcom miasta, a monument stanie na prywatnej działce - na parkingu przed dużym marketem budowlanym przy ulicy Angarskiej 14. Władze miasta ignorowały oświadczenia inicjatorów akcji, ale $\mathrm{w}$ momencie przygotowywania fundamentu pod cokół zareagowały, wysyłając na miejsce milicję. Problem rozwiązano sprawnie, zanim przeciwnicy budowy zdołali się zmobilizować. Dla władz istotne były tylko prawne uwarunkowania budowy, zwłaszcza kwestie związane $z$ umiejscowieniem pomnika. Wybór miejsca okazał się trafny, tak z punktu widzenia przestrzeni miejskiej, w której dominuje monastyr i cerkiew Znamieńska, jak i z uwagi na historię śmierci Kołczaka. Pomnik znajduje się w pobliżu miejsca, gdzie, według powszechnej opinii, wrzucono pod lód ciało rozstrzelanego wcześniej admirała. Monument jest zatem swoistym pomnikiem nad nieistniejącym grobem[23]. Interesująca jest także rzeźba na cokole pomnika - uwieczniono tu starcie czerwonoarmisty i żołnierza „białej” lub carskiej armii - bratobójczy pojedynek, którego bohaterowie wyglądają jak bliźniacy, tylko różnie umundurowani. To, co mieści się nad „potyczką” w tym kontekście - to całkowite pomie-

[23] W Rossii otkryt pamiatnik Kołczaku [online], 4 listopada 2004 [dostęp: 21 stycznia 2015], <http://news.bbc. co.uk/hi/russian/russia/newsid_398200o/3982397.stm>. 
szanie sensów, biorąc pod uwagę, co wiadomo o Kołczaku[24]. Pomnik wrósł już jednak w pejzaż miasta.

Kolejną formą upamiętnienia Kołczaka i śladów jego pobytu w Irkucku jest budynek Obwodowego Muzeum Etnograficznego. Budowlę w stylu mauretańskim, zbudowaną pod koniec XIX wieku dla Wschodniosyberyjskiego Oddziału Rosyjskiego Towarzystwa Geograficznego, opasano fryzem trzydziestu tabliczek. Na osiemnastu z nich wypisane są nazwiska znakomitych badaczy Syberii związanych z Irkuckiem - dwanaście zapisano przy oddawaniu budynku do użytku w roku 1883, a sześć na półwiecze oddziału w roku 1901. Pozostałych dwunastu tabliczek w ciągu całego stulecia nie zapełniono. W latach 60. dyskutowano o możliwości uzupełniania tabliczek w kontekście upamiętniania Władimira Obruczewa. Ostatecznie napisów nie przybyło, a Obruczewowi poświęcono zwykłą tablicę pamiątkową na budynku. W roku 2005 powrócono do problemu uzupełnienia nazwisk zasłużonych badaczy Syberii. Po dyskusjach uznano, że jedynie nazwisko „Kołczak” może być umieszczone na fryzie[25]. Podczas uroczystości w lutym 2007 roku gubernator obwodu nazwał ten moment aktem „sprawiedliwości dziejowej”.

Historia pomnika i umieszczenia nazwisk na tabliczkach stanowi splot dwóch procesów deideologizacji i „dekolonizacji” (rozumianej tu raczej jako wchodzenie samorządności lokalnej w przestrzeń miasta). Postawienie pomnika pokazało zdolność do podjęcia inicjatywy przez grupę mieszkańców miasta, jej determinację i upór w realizacji celu, jakim było oznaczenie przestrzeni miasta wyraźnie ideologicznym znakiem „wielkiej historii”. Z całej galerii postaci i wydarzeń historycznych wybór padł na Kołczaka, który nie ma swoich pomników w Rosji. Ma to podnosić znaczenie i unikatowość miasta na tle imperium.

Film Admirał, jak i problem upamiętniania Kołczaka w Rosji, wywołuje pytanie: na ile ważna jest dla współczesnych ta postać?[26] W związku z dużym zainteresowaniem filmem Admirał instytucja badania opinii publicznej w Rosji o nazwie Zasoby Opinii Społecznej [27] przeprowadziła sondaż dotyczący wojny domowej i dowódcy „białych” - Kołczaka. Na pytanie otwarte - o skojarzenia z wojną domową („Co pierwsze przychodzi ci do głowy, gdy słyszysz te słowa?”), pytani mówili częściej o ogólnym skojarzeniu ze złem wojny niż o konkretnych wydarzeniach i postaciach historycznych [28]. Na pytanie, czy znają postać

[24] Fotografia pomnika Kołczaka - <http://vk.com/ photo-328467_79778004> [dostęp: 20 stycznia 2015]. [25] Tabliczka z nazwiskiem Kołczaka na fryzie Muzeum Etnograficznego w Irkucku, patrz: <http:// vk.com/photo-328467_177553434> [dostęp: 25 stycznia 2015].

[26] Internetowa Istoriczieskaja Encykłopedia Sibiri pokazuje obecność Kołczaka w sztuce, literaturze, muzyce, $<$ http://russiasib.ru/kolchak-aleksandr-vasilevich/> [dostęp: 20 stycznia 2015].
[27] Fond Obszczestwiennowo Mnienija to niezależna grupa socjologiczna utworzona w roku 1992, wykonująca badania na zlecenie instytucji i firm w Rosji i innych (BBC, Banku Światowego, Stanford University, ambasad), patrz: www.fom.ru.

[28] Badanie pt. Grażdanskaja wojna. Aleksandr Kołczak, 11-12 października 2008, 44 podmioty Federacji Rosyjskiej, 100 miejsc zamieszkania, 1500 respondentów. Wyniki oprac. Jelena Wasiliewa, opublikowane 16 października 2008 [dostęp: 29 stycznia 2015], $<$ http://bd.fom.ru/report/map/do84122>. 
Kołczaka, uzyskano odpowiedzi: 43 proc. zna postać, 41 proc. coś o niej słyszało, 10 proc. usłyszało nazwisko pierwszy raz (8 proc. wśród ludzi z wyższym wykształceniem). Przedtem zadano pytanie o nazwiska ważnych postaci wojny domowej („czerwonych” i „białych”): najwięcej osób wymieniało W. Czapajewa (33 proc.) [29], A. Kołczaka (19 proc.), A. Denikina (13 proc.), S. Budionnego (12 proc.). Według ekspertów firmy sondażowej, wysokie miejsce Kołczaka jest ściśle związane z projekcją filmu Admirał[30]. Próba oceny postaci Kołczaka okazała się trudna dla 46 proc. pytanych, 26 proc. uważało, że jego rola jest w niektórych aspektach pozytywna, w niektórych negatywna, 18 proc. oceniło go pozytywnie, a 7 proc. negatywnie[31].

Jesienią 2014 roku przeprowadzono w Irkucku badanie wśród starszych uczniów i studentów Irkuckiego Uniwersytetu Państwowego. Pytania także dotyczyły recepcji wojny domowej, postaci Kołczaka i filmu Admirał. W ankiecie wzięło udział 135 respondentów. Na pytanie: czy wiedzą, kim był Kołczak - 41 proc. odpowiedziało: tak; 41 proc. coś słyszało; 16 proc. - pierwszy raz słyszało to nazwisko. Na pytanie o jego działalność - 35 proc. odpowiedziało: „walczył przeciwko czerwonym”; 7 proc. nazwało Kołczaka utalentowanym dowódcą, 5 proc. odpowiedziało, że walczył na Syberii i na Dalekim Wschodzie. Nikt nie nazwał go badaczem polarnym, naukowcem czy podróżnikiem. Pytano także o ogólny stosunek do tej postaci historycznej; 46 proc. miało kłopot $\mathrm{z}$ odpowiedzią na to pytanie, 27 proc. miało neutralny stosunek, 19 proc. - pozytywny, 8 proc. - negatywny[32].

Sondaż wykazał także wpływ kinematografii na kształtowanie wizerunku Kołczaka wśród młodych ludzi. W badaniu wzięło udział trzydziestu respondentów, którzy nie oglądali wcześniej ani filmu, ani serialu Admirał. Przed projekcją pytano o stosunek do admirała; 8 osób oceniło go pozytywnie, 12 - negatywnie, 10 - neutralnie. Po obejrzeniu filmu stosunek do postaci wyraźnie się zmienił. Pozytywnie oceniło Kołczaka 19 osób, 11 negatywnie, neutralnych opinii nie było. Filmowa narracja przekonała zatem wszystkich niezdecydowanych. Interesujący jest także opis cech bohatera dokonany przed i po obejrzeniu filmu. Jako pozytywne cechy wymieniano: nieustraszony oficer, utalentowany żołnierz, ofiara wojny domowej, ponadprzeciętna osobowość, mądry i wykształcony człowiek. Jako negatywne: lubiący władzę, niezrównoważony, dyktator, zły polityk, sprzedawczyk, ponury, zdrajca, tyran i ciemiężyciel. Lista cech negatywnych wymienianych przez respondentów po projekcji uległa zmianie, ale spis cech pozytywnych wyraźnie się wydłużył. Młodzi ludzie zauważyli dodatkowo takie cechy, jak: wierny

[29] Historycy podważają zasługi Czapajewa i jego mit $\mathrm{z}$ okresu radzieckiego. Była to postać prawdziwa, był dowódcą oddziału Armii Czerwonej, ale niczym szczególnym się nie wyróżnił. M. Weller, A. Burowskij, Grażdanskaja istorija biezumnoj wojny, Moskwa 2007, s. 542-543. Czapajew popularność zawdzięcza filmowi pt. Czapajew (1934) i licznym dowcipom.

[30] Zob. przyp. 26.

[31] Zob. przyp. 26.

[32] Ankieta przeprowadzona w Irkucku, na grupie 135 osób w wieku 16-24 lat, październik-listopad 2014. 
rycerz, podróżnik i badacz, oddany interesom Rosji, szczery, otwarty, szlachetny, posiadający urok osobisty[33].

Wyniki ankiet mogą być przyczynkiem do dalszych analiz. Otwarte pozostaje pytanie o trwałość i stabilność ocen, artykułowanych po obejrzeniu filmu Admirat. Być może opierają się one na emocjach, które wywołał film, i nie przyczynią się do transformacji obrazu postaci, zwłaszcza u osób już przekonanych. Widać jednak, że osoby prezentujące neutralne opinie lub mało zorientowane w tematyce łatwiej ulegają wpływowi przekazu.

Film jako zjawisko kultury masowej może w rosyjskich realiach społeczno-historycznych okazać się efektywnym narzędziem formowania stosunku widza do historii własnego państwa i jego historycznych bohaterów. Może zatem być także środkiem wykorzystywanym do realizacji polityki historycznej. 